\title{
Evaluating the Biodeterioration Enzymatic Activities of Fungal Contamination Isolated from Some Ancient Yemeni Mummies Preserved in the National Museum
}

\author{
Khalid Mohammed Naji, ${ }^{1}$ Qais Yusuf M. Abdullah, ${ }^{2}$ \\ Aida Qaseem M. AL-Zaqri, ${ }^{3}$ and Saeed M. Alghalibi ${ }^{2}$ \\ ${ }^{1}$ Department of Chemistry, Faculty of Science, Sana'a University, Sana'a, Yemen \\ ${ }^{2}$ Department of Biology, Faculty of Science, Sana'a University, Sana'a, Yemen \\ ${ }^{3}$ Department of Archaeology, Faculty of Art, Sana'a University, Sana'a, Yemen
}

Correspondence should be addressed to Khalid Mohammed Naji; khalid.m.naji@gmail.com

Received 29 July 2014; Revised 25 September 2014; Accepted 16 October 2014; Published 13 November 2014

Academic Editor: Saad Tayyab

Copyright (C) 2014 Khalid Mohammed Naji et al. This is an open access article distributed under the Creative Commons Attribution License, which permits unrestricted use, distribution, and reproduction in any medium, provided the original work is properly cited.

Sophisticated mummification using chemical preservation was prevalent in ancient Yemeni civilization as noted in the 4 th century B.C. mummies of the National Museum of Yemen, Sana', used in this study. Five of these mummies were used to evaluate hydrolytic enzymes produced as a result of fungal contamination. Forty-seven fungal species were isolated, thereby reflecting a high degree of contamination which may have resulted from the poor ventilation and preservation system. Aspergillus was the most common genus isolated (48.9\%). Fifteen isolates exhibited ability to produce cellulase (EC; 3.2.1.4), Aspergillus candidus being the highest celluloseproducer. Pectin lyase (PL, EC; 4.2.2.2) and pectin methyl esterase (PME, EC; 3.1.1.11) were produced by Trichoderma hamatum, whereas chitinase (EC; 3.2.1.14) was produced by Aspergillus niger. Protease activity was noted by only Cladosporium herbarum. The higher activities of these fungal hydrolytic enzymes represent the major threats of biodeterioration including deteriorating linen bandages as well as the mummy bodies. Therefore, it is recommended to improve the preservation system of the mummies at the National Museum to minimize the contamination up to the lowest level and protect the mummies from biodeterioration.

\section{Introduction}

Human mummies are extremely susceptible to damage from environmental factors [1]. There are a number of abiotic and biotic factors, such as pollution, light, humidity, temperature, microorganisms, and insects, that have deteriorating effects on museum materials [2]. The most serious damage on mummies occurs by microorganisms such as bacteria, actinomycetes, and fungi $[1,3,4]$.

In an indoor environment, fungi are the most hazardous microorganisms responsible for the biocontamination of museum collections. Unlike bacteria whose growth in museums is limited by their need for water, fungi are able to grow at relatively low levels of temperature and humidity such as those usually maintained in the museums $[5,6]$. Even in quite harsh conditions including dryness and low temperature, fungal spores are able to survive for a long time [7]. Fungi are usually present in display and storage conditions of museums $[8,9]$.

Fungal degradation is one of the highest risk factors for deterioration of ancient mummies [10, 11]. The deterioration by fungi seems to be a predominant feature in the museums of many countries all over the world $[8,12]$. Fungi excrete enzymes that digest organic matter, thereby altering and weakening those materials. In addition, many molds contain colored substances that can cause stains and spots on textiles and decrease the strength of the fabric. Many fungi can be dangerous to people and in some cases pose a major health hazard and cause zoonotic superficial infections as a consequence of invading keratinized tissues of skin, hair, and nails $[13,14]$.

Fungal biodeterioration results in a change in the quality or value of a material and makes it less functional in utilization terms. A battery of extracellular hydrolytic enzymes 
TABLE 1: List of ancient mummy's samples collected from National Museum of Yemen at Sana'a (NMS) during this investigation.

\begin{tabular}{llc}
\hline No. & Mummy description & Source \\
\hline M1 & A male skeleton of mummy dried naturally (dehydrated body) & Age years \\
\hline M2 & $\begin{array}{l}\text { Human mummified remains dried naturally (dehydrated body) } \\
\text { showing mold deterioration }\end{array}$ & Al-Hymah-Sana'a \\
\hline M3 & A typical Yemeni mummy wrapped with linen cloth & Al-Tawilah Al-Mahwit \\
\hline M4 & Severe fragile and damaged human mummified remains & Al-Tawilah Al-Mahwit \\
\hline M5 & $\begin{array}{l}\text { Human mummified body dried naturally (dehydrated body) } \\
\text { showing linen textiles without a conservation process. } \\
\text { Deterioration of textiles eventually causes complete loss }\end{array}$ & Al-Tawilah Al-Mahwit \\
\hline
\end{tabular}

* A mummy embalmed or treated with chemicals, or it may have been naturally desiccated under extreme cold, dryness, or even lack of air.

excreted by fungi results in the formation of acidic products that cause chemical alteration of the material under attack [15]. Cellulases catalyze hydrolysis of cellulose, break internal bonds to disrupt its crystalline structure, and expose individual cellulose polysaccharide chains [16]. Pectinases catalyze hydrolysis of pectic substances readily soluble in water. Pectolytic enzymes are divided into two classes, namely, pectinesterases and pectin depolymerases. The former enzyme deesterifies pectin by the removal of methoxy residues and is called pectin methoxy esterase (PME), while the latter splits the main chain and is further classified as polygalacturonase (PG) and pectin lyases (PL) [17-19]. Chitinases are glycosyl hydrolases having the ability to degrade $\beta$ 1, 4-linked insoluble linear polymers of $N$-acetylglucosamine (chitin) directly to low molecular weight chitooligomers [20]. Proteases, a complex group of hydrolytic enzymes, hydrolyze proteins into small peptides and amino acids by the addition of water across amide bonds. They have evolved different classes of proteases that perform the same reaction by using completely different catalytic mechanisms. Fungi are known to produce acid, neutral, alkaline, and metalloproteases. A single organism can produce more than one type of protease [21]. Fungal proteases are active over a wide $\mathrm{pH}$ range $(\mathrm{pH} 4$ to 11) and exhibit broad substrate specificity [22].

The ancient Yemeni mummies discovered in 1983 in mountain caves near Shebam al-Giras were rescued by the Archeology Department Expedition of University of Sana'a [23]. The Yemeni mummies are different from those of Egypt. They are older and go back to the 4 th century B.C. according to results of radiocarbon analysis of the leather and linen wrappings [24]. The dead bodies were treated different from the Egyptian ones. Local materials used in mummification to absorb moisture such as raá plant (Aerva javanica), henna (Lawsonia inermis), myrrh, and other aromatic plants were used to preserve the corpses. Oxides of iron and sulfur were used to fix proteins in the corpse. The process was completed with the corpses being wrapped in linen (Linum usitatissimum) bandages. The bandaging took place over an elongated period of days [25]. Most of the materials used in the mummification are natural organic substances. Hence, these mummies are liable to deterioration. In addition, the storage conditions of the mummified corpses in the museum display are in unsuitable environmental conditions. These mummies are of special importance as they depict ancient
Yemeni civilization and its use of advanced medical and scientific knowledge in the preservation of the corpses.

This study aimed at screening of fungal contamination of five Ancient Yemeni mummies preserved in the National Museum of Yemen at Sana'. The fungal hydrolytic enzymes assessed were cellulase, PL, PME, chitinase, and protease. This in turn will help in our understanding for the use of better preservative conservation procedures in order to safeguard the mummies from future damage.

\section{Materials and Methods}

2.1. Mummy Samples. Five mummies preserved in the National Museum of Yemen at Sana'a were used in this study for the collection of fungal contamination. The details of the mummies used are as described in Table 1.

2.2. Screening of Fungal Contamination. Samples were taken from different skin areas (face, hands, and feet) of the five mummies. Fungi were isolated using the conventional methods of swabbing and streaking [26] on Potato Dextrose Agar (PDA). Plates incubated at $27 \pm 1^{\circ} \mathrm{C}$ for 7 days. Three replicates were prepared for each sample. The resultant colonies were isolated, purified, and identified. Pure cultures of the identified fungi were transferred to a slant and used for physiological studies. Fungi were identified based on their morphology according to Raper and Fennell [27], Ellis [28], and Barnett and Hunter [29].

2.3. Screening the Hydrolytic Enzymatic Activity of Isolated Fungi. Twenty-one isolates were examined for their ability to produce common hydrolytic enzymes. Standard methods were used for assay of the following enzyme activities: cellulase [30], pectinase [31], chitinase [32], and protease [33].

2.4. Production of Enzymes in Liquid Nutrient. The isolates that were found to exhibit highest activity of each enzyme on solid media were grown in liquid media for further analysis.

2.5. Growth Condition. The fungi were grown in Erlenmeyer flasks $(100 \mathrm{~mL})$ containing $25 \mathrm{~mL}$ of the liquid growth medium. After sterilization, the flasks were inoculated with a single $6 \mathrm{~mm}$ disc cut out from the margin of $5 \mathrm{~d}$ colony of the fungus grown on Czapek's agar medium. The inoculated 
flasks were incubated as stationary culture at $30^{\circ} \mathrm{C}$ for 7,14 , and 21 days [34]. The experiments were carried out in triplicate.

\subsection{Growth Medium}

Cellulase. $100 \mathrm{~mL}$ of the liquid medium contained cellulose, $1 \mathrm{~g} ;\left(\mathrm{NH}_{4}\right)_{2} \mathrm{SO}_{4}, 0.14 \mathrm{~g} ; \mathrm{K}_{2} \mathrm{HPO}_{4}, 0.6 \mathrm{~g} ; \mathrm{KH}_{2} \mathrm{PO}_{4}, 0.20 \mathrm{~g}$; and $\mathrm{MgSO}_{4} \cdot 7 \mathrm{H}_{2} \mathrm{O}, 0.01 \mathrm{~g}$ in distilled water [35]. An isolate of Aspergillus candidus was inoculated into sterile media for the production of cellulase.

Pectinase. Trichoderma hamatum isolate was used for the production of PL and PG enzymes using the medium described by Eggins and Pugh [36]. The composition per $1000 \mathrm{~mL}$ was pectin, $10 \mathrm{~g}$; L-asparagine, $0.5 \mathrm{~g}$; $\left(\mathrm{NH}_{4}\right)_{2} \mathrm{SO}_{4}$, 0.5 g; $\mathrm{KH}_{2} \mathrm{PO}_{4}, 1.0 \mathrm{~g} ; \mathrm{KCl}, 0.5 \mathrm{~g} ; \mathrm{CaCl}_{2}, 0.2 \mathrm{~g}$; yeast extract, $0.5 \mathrm{~g} ; \mathrm{MgSO}_{4} \cdot 7 \mathrm{H}_{2} \mathrm{O}, 0.2 \mathrm{~g}$ in distilled water. The $\mathrm{pH}$ was adjusted to 5 using acetate buffer.

Chitinase. Aspergillus niger isolate was used for the production of chitinase using the medium described by Hsu and Lockwood [32]. $100 \mathrm{~mL}$ of liquid growth medium contained $\mathrm{NaNO}_{3}, 0.5 \mathrm{~g} ; \mathrm{KH}_{2} \mathrm{PO}_{4}, 0.2 \mathrm{~g} ; \mathrm{KCl}, 0.1 \mathrm{~g}$; yeast extract, $0.05 \mathrm{~g}$; $\mathrm{MgSO}_{4} 7 \mathrm{H}_{2} \mathrm{O}, 0.05 \mathrm{~g}$ in distilled water. The $\mathrm{pH}$ was adjusted to 5 using acetate buffer.

Protease. Cladosporium herbarum isolate was used for protease production in liquid medium as described by Ali [37]. $1000 \mathrm{~mL}$ of liquid growth medium contained $\mathrm{K}_{2} \mathrm{HPO}_{4}, 1 \mathrm{~g}$; $\mathrm{MgSO}_{4} \cdot 7 \mathrm{H}_{2} \mathrm{O}, 0.5 \mathrm{~g} ; \mathrm{KCl}, 0.5 \mathrm{~g} ; \mathrm{FeSO}_{4} \cdot 7 \mathrm{H}_{2} \mathrm{O}, 0.01 \mathrm{~g}$; sucrose, $30 \mathrm{~g}$; casein, $1 \%(\mathrm{w} / \mathrm{v})$ in distilled water. The $\mathrm{pH}$ was adjusted to 5 using acetate buffer.

2.7. Enzymes Assay. The culture filtrates were used as crude enzyme preparations for all mentioned enzymes.

Cellulase activity was measured by estimating the liberated amount of reducing sugar using dinitro salicylic acid (DNS), according to Miller [38] with the modification of Bernfeld [39] using glucose for the standard curve. The absorbance was read at $540 \mathrm{~nm}$ using boiled enzyme as control. One unit of cellulase activity is defined as the quantity of enzyme that catalyzes the liberation of $1 \mu \mathrm{mol} / \mathrm{min}$ of reducing sugar measured using glucose as standard.

Pectinase. Two enzymes of pectinase family were estimated.

(a) Pectin lyase (PL) activity was assayed spectrophotometrically by determining uronide at $235 \mathrm{~nm}$ [40]. $3 \mathrm{~mL}$ of reaction mixture contained $0.1 \%$ pectin in $0.05 \mathrm{M}$ of Tris- $\mathrm{HCl}$ buffer $(\mathrm{pH} 8)$ and $0.5 \mathrm{~mL}$ of culture filtrate. The reaction mixture was incubated at $30^{\circ} \mathrm{C}$ for 3 hours. Then $3 \mathrm{~mL}$ of $0.01 \mathrm{~N} \mathrm{HCl}$ and $1 \mathrm{~mL}$ of reaction mixture were mixed and the optical density read. One unit of PL activity is defined as the amount of enzyme which causes an increase in absorbance of $0.01 \mathrm{in} 30 \mathrm{~min}$.

(b) Pectin methyl esterase (PME) activity was assayed based on the method described by Kertesz [41] and modified by Olutiola and Akintunde [42]. In sterilized $25 \mathrm{~mL}$ conical flask, $2 \mathrm{~mL}$ of culture filtrate was mixed with $5 \mathrm{~mL}$ of $1.2 \%$ pectin (in $0.05 \mathrm{M}$ Tris- $\mathrm{HCl}$ buffer containing $5 \mathrm{mM}$ sodium carbonate, $\mathrm{pH} 8$ ). The flask was incubated in water bath at $30^{\circ} \mathrm{C}$ for $3 \mathrm{~h}$ followed by titration with $0.02 \mathrm{~N} \mathrm{NaOH}$ to adjust $\mathrm{pH}$ to 8 . One unit of PME activity was defined as the amount of enzyme required for addition of $1 \mu$ equivalent of $\mathrm{NaOH}$ per hour to maintain the reaction at $\mathrm{pH} 8$.

Chitinase activity was estimated according to Monreal and Reese [43]. $5 \mathrm{~mL}$ reaction mixture contained $1 \%$ colloidal chitin in phosphate buffer ( $\mathrm{pH} 5$ ) and $1 \mathrm{~mL}$ of culture filtrate. The mixture was incubated at $37^{\circ} \mathrm{C}$ for $1 \mathrm{~h}$, reaction arrested by adding $0.5 \mathrm{~mL}$ of DNS, boiled for $15 \mathrm{~min}$ in a water bath, and cooled to room temperature. Optical density was then measured at $540 \mathrm{~nm}$ against a suitable blank. The reducing sugar released was determined from the standard curve of glucose. One unit of chitinase activity is defined as the amount of enzyme, which produced $1 \mu \mathrm{mol}$ of reducing sugar $\min ^{-1}$ under assay conditions.

Protease activity was estimated by the method of Folin and Ciocalteu [44]. The reaction mixture containing $5 \mathrm{~mL}$ of $0.65 \%$ casein ( $\mathrm{pH} 7.5$ ) and $1 \mathrm{~mL}$ of enzyme extract was mixed well by swirling and incubated at $37^{\circ} \mathrm{C}$ for $10 \mathrm{~min}$. The reaction was arrested by adding $5 \mathrm{~mL}$ of cold $10 \%$ trichloroacetic acid and incubated at $37^{\circ} \mathrm{C}$ for $30 \mathrm{~min}$. It was filtered through Whatman filter paper and the filtrate thus obtained was used for color development. $5 \mathrm{~mL}$ of $\mathrm{Na}_{2} \mathrm{CO}_{3}$ and $1 \mathrm{~mL}$ of Folin-Ciocalteu's (FC) reagent were added to an aliquot of the filtrate and incubated at $37^{\circ} \mathrm{C}$ for $30 \mathrm{~min}$ and absorbance was read at $660 \mathrm{~nm}$. The amount of amino acids released was calculated using standard curve of tyrosine. One unit of protease activity is defined as the amount of enzyme that produced $1 \mu \mathrm{mol}$ of tyrosine $\min ^{-1}$ under assay conditions.

Protein Content. Soluble protein was estimated according to Lowry et al. method [45], using bovine serum albumin (BSA) as standard.

2.8. Determination of Dry Weight. Fungal mycelia were separated from the growth medium by filtration through Whatman no. 1 filter paper. The mycelia were then washed and dried in an oven at $60^{\circ} \mathrm{C}$ for $24 \mathrm{~h}$. The dry weight of the mycelia was recorded.

2.9. Statistical Analysis. Two-way analysis of variance (ANOVA) was used for statistical evaluation of enzymes activities and dry weight by using GraphPad Prism version 6. Data were shown as mean $\pm \mathrm{SD}$. The value of $P<0.05$ was considered statistically significant.

\section{Results and Discussion}

Fifteen species belonging to 10 genera of fungi were isolated from five ancient Yemeni mummies on PDA. The total count of fungi isolated from all samples was 47 (Table 2). 
TABLE 2: Fungal species isolated from some ancient Yemeni mummies collection of National Museum in Sana’a.

\begin{tabular}{|c|c|c|c|c|c|c|c|c|}
\hline Fungi isolated & M1 & M2 & M3 & M4 & M5 & Sp. T.C & T.C & $\%$ \\
\hline Aspergillus sp. & & & & & & & 23 & 48.94 \\
\hline A. candidus & - & - & - & 2 & - & 2 & & 4.26 \\
\hline A. flavus & 5 & - & - & - & - & 5 & & 10.64 \\
\hline A. fumigatus & - & 2 & - & - & - & 2 & & 4.26 \\
\hline A. niger & 4 & 1 & 3 & 1 & 3 & 12 & & 25.53 \\
\hline A. ustus & - & - & - & - & 2 & 2 & & 4.26 \\
\hline Cladosporium sp. & & & & & & & 7 & 14.89 \\
\hline C. herbarium & - & - & 2 & - & - & 2 & & 4.26 \\
\hline C. cladosporioides & - & 4 & - & 1 & - & 5 & & 10.64 \\
\hline Penicillium sp. & & & & & & & 6 & 12.76 \\
\hline P. echinulatum & - & - & - & 3 & - & 3 & & 12.76 \\
\hline Penicillium sp. & - & 2 & - & 1 & - & 3 & & 12.76 \\
\hline Aureobasidium pullulans & - & - & - & 1 & - & & 1 & 2.13 \\
\hline Chaetomium thermophilum & - & - & - & - & 1 & & 1 & 2.13 \\
\hline Mucor circinelloides & - & - & 1 & - & - & & 1 & 2.13 \\
\hline Scopulariopsis koningii & - & - & - & 1 & - & & 1 & 2.13 \\
\hline Stachybotrys chartarum & - & - & - & - & 1 & & 1 & 2.13 \\
\hline Trichoderma hamatum & - & - & 1 & - & - & & 1 & 2.13 \\
\hline Ulocladium chartarum & - & - & - & 1 & - & & 1 & 2.13 \\
\hline Sterile mycelium & - & 1 & 1 & 1 & 1 & & 4 & 8.5 \\
\hline Total & 9 & 10 & 8 & 12 & 8 & & 47 & \\
\hline
\end{tabular}

$\mathrm{M}=$ mummy; $\mathrm{NI}=$ number of isolates; $\mathrm{T} . \mathrm{C}=$ total count; $\%=$ percentage of occurrence.

Mummy 1 (M1) had the lowest fungal contamination, that is, only two species of Aspergillus (Figure 1). In contrast, M4 showed the highest contamination with 12 isolates of 9 species (Figure 1). The other mummies showed moderate contamination. According to the numbers of isolated fungi from the five mummies, the order from higher to lower contamination is as follows: M4 > M2 = M5 > M3 > M1 (Figure 1).

The diversity of fungal profile of each mummy, although preserved in the same museum, may have resulted from environmental conditions, which differ in each room inside the museum due to several factors including the construction and design of the building. Also, the place from which the mummies were unearthed varies. Each mummy was preserved in a separate room, and preservation conditions vary from room to room in terms of ventilation, humidity, and temperature (data not shown). In addition to that, some mummies were treated by disinfectant whereas others were not.

Aspergillus was the most common genera isolated from the mummy samples with high frequency of $48.94 \%$ of the total fungal count, the most common species being A. niger (25.53\%) followed by A. flavus (10.63\%), while $A$. fumigatus, A. candidus, and A. ustus were isolated in low frequency. Cladosporium and Penicillium were isolated in moderate frequency representing $14.89 \%$ and $12.76 \%$, respectively. Aureobasidium pullulans, Chaetomium thermophilum, Mucor circinelloides, Scopulariopsis koningii, Stachybotrys chartarum, Trichoderma hamatum, and Ulocladium chartarum were isolated in rare incidence from mummy samples.
Our results exhibited similar fungal contamination when compared to isolates from Egyptian mummies. These included Alternaria tenuis, Aspergillus humicola, Aspergillus niger, Chaetomella horrid, Chaetomium globosum, Hormodendrum viride, and Penicillium corylophilum [11]. Twentythree mummies from cemeteries and caves of northern Mexico were found to have mainly Penicillium, Aspergillus, Cladosporium, Alternaria, Candida tropicalis, and Candida albicans [46]. Also three species of Aspergillus and one of Alternaria were found to be associated with open deteriogens skeleton of giraffe in zoological museum of Punjab University in Lahore India [47].

Twenty-four isolates were examined for their ability to produce cellulase, pectinase, chitinase, and protease. Among these, 15 isolates exhibited enzymatic potential (Table 3). Cellulase enzymes degrade cellulose to disaccharides, while endoglucanases cut the cellulose chain in a random fashion and exoglucanases successively remove single cellobiose or glucose units from the nonreducing end of the cellulose chain [10]. In this study Aspergillus candidus, Aureobasidium pullulans, Ulocladium chartarum, Cladosporium cladosporioides, A. ustus, and Penicillium sp., respectively, exhibited high ability to produce cellulolytic activity based on the zone area. Similar results showed that Penicillium sp. produced high activity of cellulose [48]. On the other hand, enzyme extract obtained from $A$. niger and $A$. terreus was found to be rich in $\beta$-glucosidase [49]. Aspergillus candidus was prepared for quantitative estimation of cellulase; it showed significant reduction in cellulase activity with time of incubation period (Figure 2(a)). Ancient Yemeni mummies are 2000 years old, 


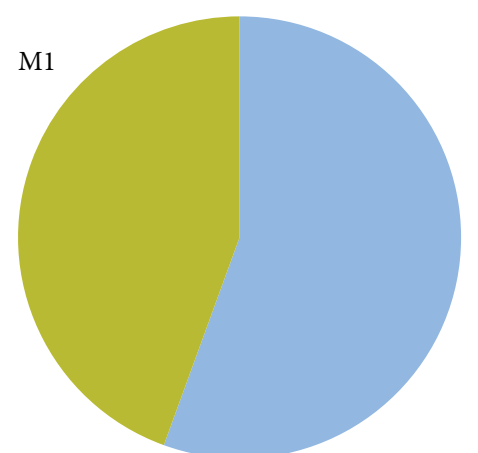

Total $=9$

Asp. flavus

Asp. niger

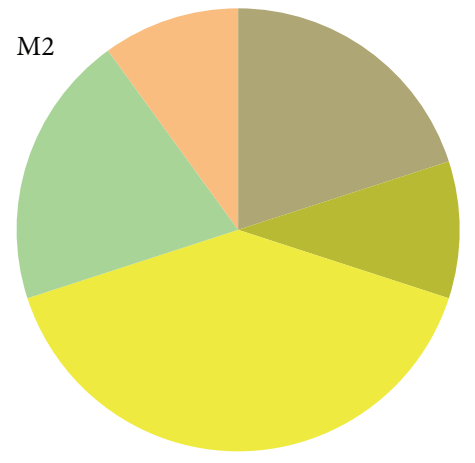

Total $=10$

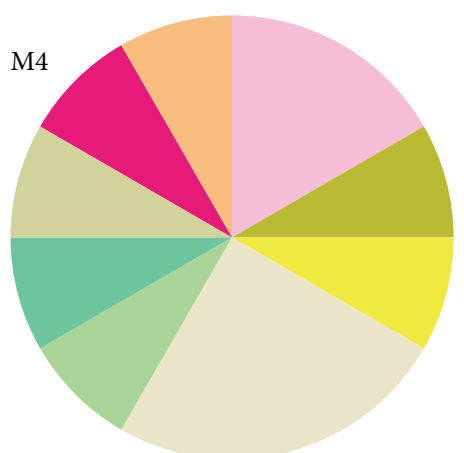

Total $=12$
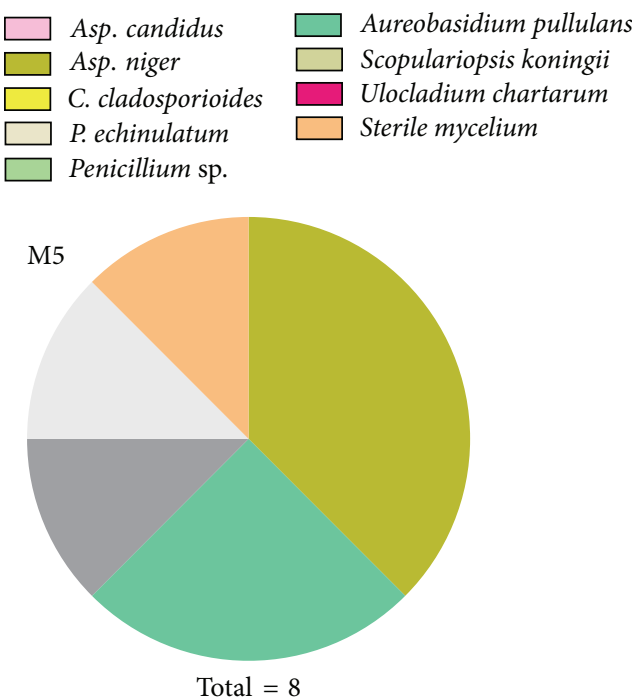
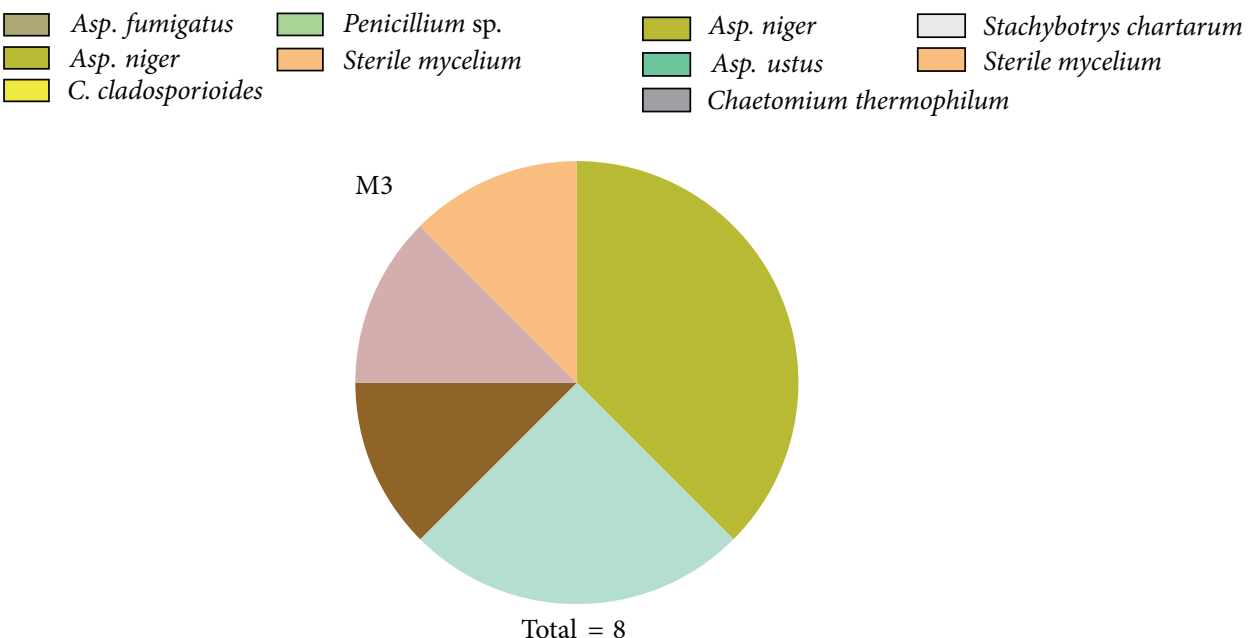

Total $=8$

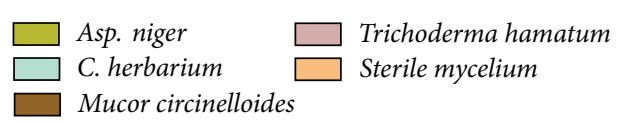

Figure 1: Percentage of mummy's contamination by different species of fungi ( $\mathrm{M} 1=$ mummy sample no. 1 ; M2 = mummy sample no. 2; M3 $=$ mummy sample no. 3; M4 = mummy sample no. 4; M5 = mummy sample no. 5; Total indicates the total no. of fungal species isolated from each mummy). 
TABLE 3: Screening of enzymatic activity of some fungal species isolated from ancient Yemeni mummies.

\begin{tabular}{|c|c|c|c|c|c|c|}
\hline \multirow{2}{*}{ Fungal species } & \multirow{2}{*}{ NIT } & \multirow{2}{*}{ Cellulase } & \multicolumn{2}{|c|}{ Pectinase } & \multirow{2}{*}{ Chitinase } & \multirow{2}{*}{ Protease } \\
\hline & & & PL & PME & & \\
\hline Aspergillus candidus & 2 & $\mathrm{H}$ & N.D & $\mathrm{H}$ & N.D & N.D \\
\hline Aspergillus flavus & 1 & N.D & N.D & N.D & N.D & N.D \\
\hline Aspergillus fumigatus & 1 & N.D & N.D & N.D & N.D & N.D \\
\hline Aspergillus niger & 6 & N.D & N.D & N.D & $\mathrm{M}$ & N.D \\
\hline Aspergillus ustus & 1 & $\mathrm{H}$ & N.D & N.D & N.D & N.D \\
\hline Cladosporium herbarium & 1 & N.D & N.D & N.D & N.D & $\mathrm{M}$ \\
\hline Chaetomium cladosporioides & 1 & $\mathrm{H}$ & N.D & N.D & N.D & N.D \\
\hline Pencillium echinulatum & 1 & N.D & $\mathrm{H}$ & $\mathrm{H}$ & N.D & N.D \\
\hline \multirow{2}{*}{ Pencillium sp. } & 1 & N.D & N.D & N.D & $\mathrm{M}$ & N.D \\
\hline & 2 & $\mathrm{H}$ & N.D & N.D & N.D & N.D \\
\hline Aureobasidium pullulans & 1 & $\mathrm{H}$ & N.D & N.D & N.D & N.D \\
\hline Chaetomium thermophilum & 1 & M & N.D & N.D & N.D & N.D \\
\hline Mucor circinelloides & 1 & $\mathrm{~W}$ & M & $\mathrm{H}$ & N.D & N.D \\
\hline Scopulariopsis koningii & 1 & N.D & $\mathrm{H}$ & N.D & N.D & N.D \\
\hline Stachybotrys chartarum & 1 & M & M & N.D & N.D & N.D \\
\hline Trichoderma hamatum & 1 & N.D & $\mathrm{H}$ & $\mathrm{H}$ & N.D & N.D \\
\hline Ulocladium chartarum & 1 & $\mathrm{H}$ & N.D & N.D & N.D & N.D \\
\hline
\end{tabular}

$\mathrm{NIT}=$ number of isolates tested; $\mathrm{PL}=$ pectin lyase; $\mathrm{PME}=$ pectin methyl esterase; $\mathrm{N} . \mathrm{D}=$ no enzyme was detected; $\mathrm{W}=$ weak $>0.5 ; \mathrm{M}=$ moderate $0.5-0.9 ; \mathrm{H}$ $=$ high $<10 \mathrm{~mm}$.

and their mummification procedure contains many botanical materials. Plenty of species able to produce cellulase suggest that this enzyme is the main cause of degradation of linen bandages of mummies and other materials.

Pectinolytic activity is one of the most important extracellular enzymes of fungi which hydrolyzes pectic substance commonly present in plant cell walls [50]. Our results revealed that, among the tested fungi, Penicillium echinulatum and Trichoderma hamatum showed the highest pectolytic activity for both pectinases enzymes, pectin methyl esterase (PME) and pectin lyase (PL). These results are in agreement with many studies that have shown Trichoderma sp. [51] and Pencillium sp. to be the most common pectinase producers [50]. In contrast, Aspergillus sp. showed the highest pectinolytic activity [52] followed by Scopulariopsis koningii and Mucor circinelloides. Activities of PL and PME from Trichoderma hamatum did not show any difference in the specific activity of both enzymes in the second week of incubation (Figures 2(b) and 2(c)), but in the third week both showed significant elevation (Table 4). This suggests that pectinase enzymes are involved in fungi metabolism and may help in its growth adaption. These enzymes play an important role in deteriorating linen bandages as well as the mummy.

Results of our study show that $A$. niger and $P$. citrinum were able to produce chitinase enzyme. These results are similar to high chitinolytic activity of $A$. niger [53]. However, Trichoderma viride showed the maximum chitinolytic activity from eight fungal species belonging to 5 genera isolated from agricultural soil sample [54]. The activity of chitinase produced by $A$. niger showed acute reduction in the second week of incubation time when compared to the first week
TABle 4: Two-way ANOVA statistical test of comparative enzymes specific activities (SA) during incubation period.

\begin{tabular}{lccc}
\hline & \multicolumn{3}{c}{$P$ value } \\
& W2 versus W1 & W3 versus W1 & W3 versus W2 \\
\hline Cellulase & $<0.0001$ & $<0.0001$ & 0.0047 \\
PL & 0.9533 & 0.0013 & 0.0011 \\
PME & 0.9905 & 0.0011 & 0.0010 \\
Chitinase & $<0.0001$ & $<0.0001$ & 0.8624 \\
Protease & 0.0247 & 0.0129 & 0.0014 \\
\hline
\end{tabular}

$\mathrm{W} 1=$ after one week; $\mathrm{W} 2$ = after 2 weeks; $\mathrm{W} 3=$ after 3 weeks.

(Figure 2(b)). This suggests that chitinase enzyme of $A$. niger isolated from mummy skin is not involved in the growth adaptation of the isolates.

Proteolytic enzymes are a large group of enzymes that cleave the peptide bonds of proteins to small fragments and amino acids. Fungi cause proteolysis of collagen which is dependent on many factors such as storage and environmental conditions, in addition to presence of certain substances that reside on the mummy's skin [10]. In our results, only one fungal isolate was able to produce proteolytic activity (Table 2). This isolate was $C$. herbarium. The proteolytic activity was found to reduce after 2 weeks of incubation whereas, after 3 weeks, it was elevated by 2 -fold (Figure 2(c)). In contrast, the fungi from different source than mummy showed higher proteolytic activity. $72.2 \%$ of 54 fungal isolates showed proteolytic activity [55].

Identifying the fungal species and the factors enhancing their growth is an essential step for the success in establishing 


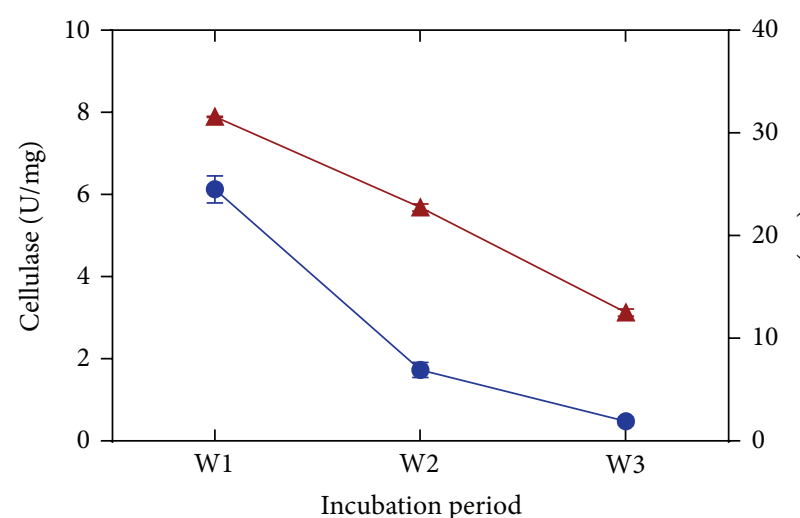

(a)

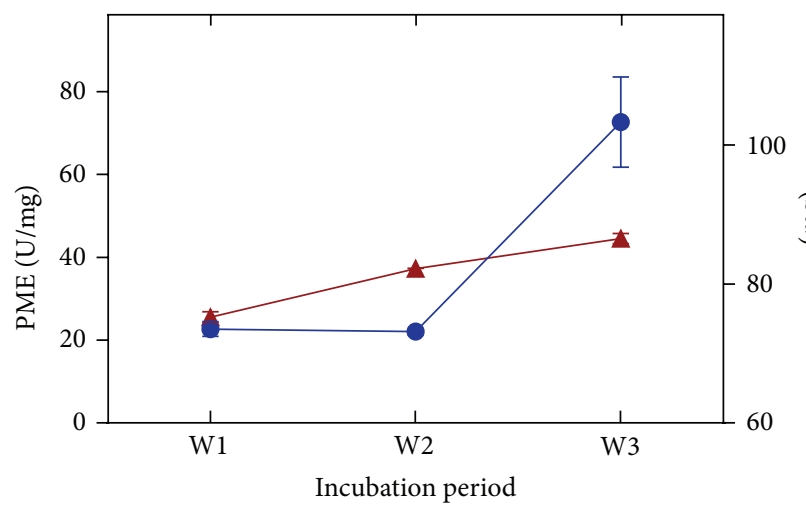

(c)

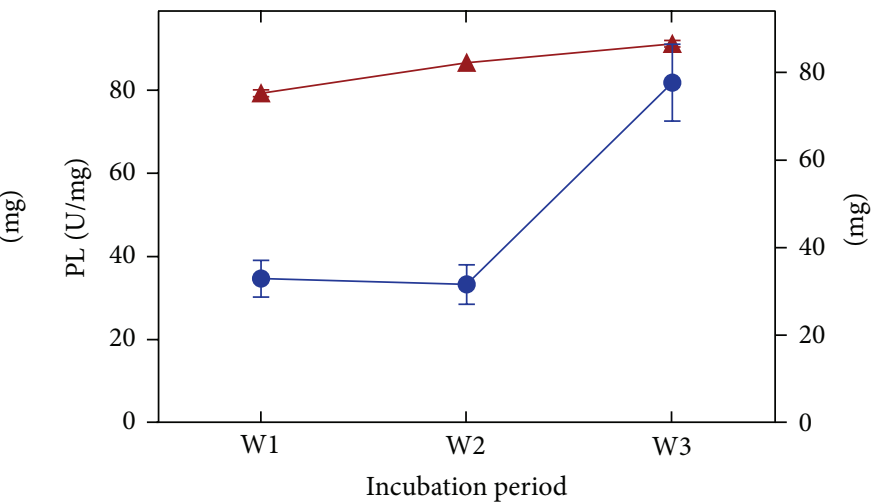

(b)

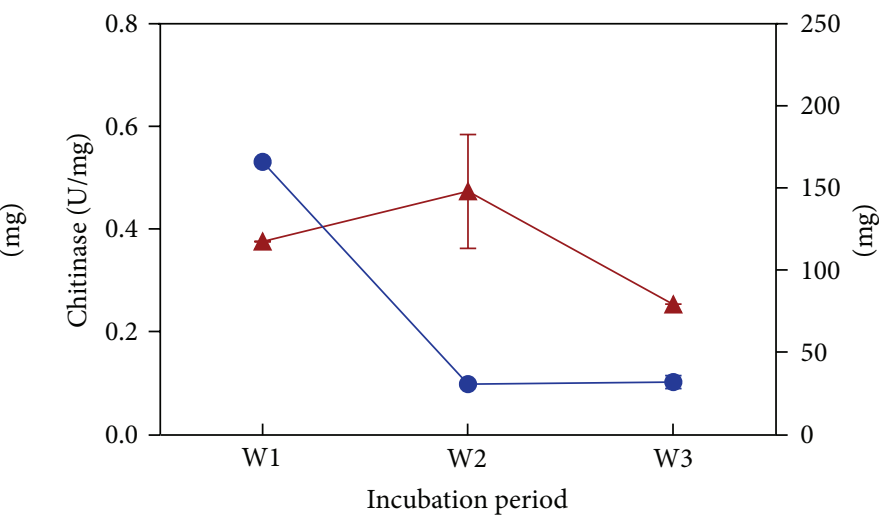

(d)

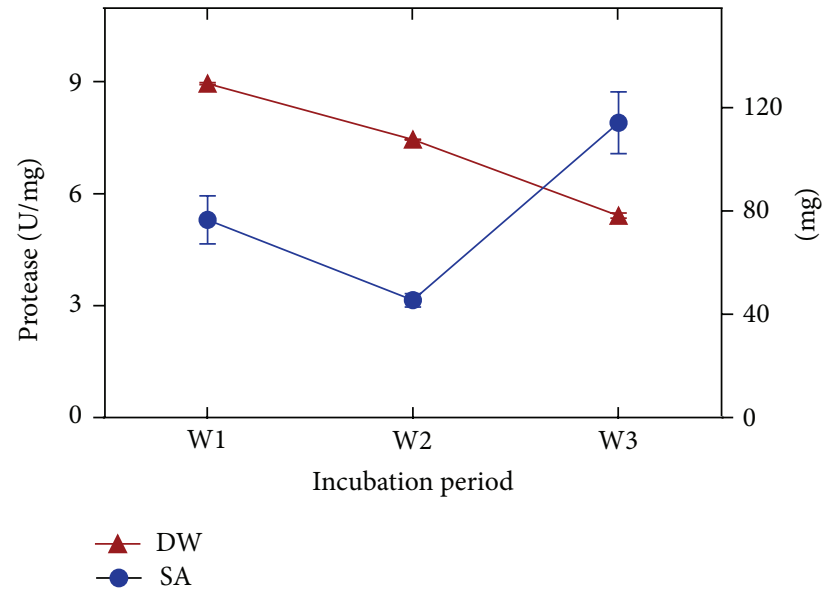

(e)

FIgURE 2: Levels of specific activity (SA) (U/mg protein) during growth incubation at $28^{\circ} \mathrm{C}$ (left $Y$-axis) for (a) cellulase from Aspergillus candidus, (b) chitinase from Aspergillus niger, (c) protease from Cladosporium herbarum, (d) pectin lyase (PL) from Trichoderma hamatum, (e) pectin methyl esterase (PME) from Trichoderma hamatum. Right $Y$-axis indicates the effect of incubation period on dry weight (DW) of each fungus growth. Data presented in these graphs are mean \pm standard division for double measures of three separate repeats.

a proper and effective strategy for preservation of the collection of mummies in museums. The fungal problem should be addressed either by controlling physical conditions of the surrounding environment in which they are stored/displayed or by the treatment with biocides. Control of the environmental conditions is the best means of protecting mummies.

\section{Conclusion}

It can be concluded that the higher degree of contamination of the ancient Yemeni mummies preserved in the National Museum of Yemen may result from the poor level of preservation conditions. Also the higher activity of hydrolytic enzymes including cellulase, PL, PME, chitinase, 
and protease from the isolated fungi species represents the major threat that can cause biodeterioration of the ancient Yemeni mummies. Therefore, it is recommended to improve the preservation systems of the mummies at the National Museum to minimize the contamination to the lowest level, which in turn will protect the mummies from biodeterioration.

\section{Conflict of Interests}

The authors declare that there is no conflict of interests regarding the publication of this paper.

\section{References}

[1] A. Arya, A. R. Shah, and S. Sadasivan, "Indoor aeromycoflora of Baroda museum and deterioration of Egyptian mummy," Current Science, vol. 81, no. 7, pp. 793-799, 2001.

[2] A. E. David, "Conservation of mummified Egyptian remains," in Science in Egyptology: Proceedings of the Science in Egyptology Symposia, A. R. David, Ed., Manchester University Press, Manchester, UK, 1986.

[3] M. L. E. Florian, "Conidial fungi (mould, mildew) biology: a basis for logical prevention, eradication and treatment for museum and archival collections," Leather Conservation News, vol. 10, no. 1, pp. 1-29, 1994.

[4] O. Abdel-Kareem, J. Szostak-Kotowa, W. Barabasz, I. Paśmionka, and A. Galus, "Fungal biodeterioration of ancient Egyptian textiles, part I: survaying study for the most dominant fungi on ancient Egyptian textiles," in Drobnousreoje W Środowisku Występowanie, Aktywność i Znaczenie, Wyd, pp. 279-290, AR Kraków, 1997.

[5] W. P. Lull and P. N. Banks, Conservation Environment Guidelines for Libraries and Archives, vol. 102, Canadian Council of Archives (CCA), Ottawa, Ontario, Canada, 1995.

[6] S. Ogden, "Temperature, relative humidity, light and air quality: basic guidelines for preservation," in Preservation of Library and Archival Materials: A Manual, S. Ogden, Ed., p. 412, Northeast Document Conservation Center (NEDCC), Andover, Mass, USA, 3rd edition, 1999.

[7] M. L. Florian, Fungal Facts: Solving Fungal Problems in Heritage Collections, Archetype Publications, London, UK, 2002.

[8] M. R. Giuliani and M. P. Nugari, "A case of fungal biodeterioration on an ancient textile," in Proceedings of the 9th Triennial Meeting of the ICOM Committee for Conservation, pp. 305-307, Washington, DC, USA, 1993.

[9] M. L. Florian, Fungal Facts, Solving Fungal Problems in Heritage Collections, Archetype Publications, London, UK, 2004.

[10] R. Martínez, F. Hernández, B. Millán, P. Manzano, and J. Méndez, "Effectiveness of imazalil to control the effect of fungal deterioration on mummies at the Mexico City Museum 'El Carmen," Revista Iberoamericana de Micología, vol. 24, no. 4, pp. 283-288, 2007.

[11] A. Elnaggar, A. Sahab, S. Ismail, G. Mahgoub, and M. Abdelhady, "Microbial study of Egyptian mummies: an assessment of enzyme activity, fungicides and some mummification materials for the inhibition of microbial deterioration," e-Conservation Magazine, no. 16, pp. 39-49, 2010.

[12] N. Valentin, "Microorganisms in museum collections," Coalition, vol. 19, pp. 1579-8410, 2010.
[13] R. Kowalik, "Microbiodeterioration of library materials. Part 2. Microbiodecomposition of basic organic library materials," Restaurator, vol. 4, no. 3-4, pp. 135-219, 1980.

[14] I. Weitzman and R. C. Summerbell, "The dermatophytes," Clinical Microbiology Reviews, vol. 8, no. 2, pp. 240-259, 1995.

[15] R. J. Koestler, "Polymers and resins as food for microbes," in Of Microbes and Art: The Role of Microbial Communities in the Degradation and Protection of Cultural Heritage, O. Ciferri, P. Tiano, and G. Mastromei, Eds., p. 250, Kluwer Academic/Plenum Publisher Company, New York, NY, USA, 2000, (International Conference on Microbiology and Conservation (ICMC), Florence, Italy, pp. 153-167).

[16] M. K. Bhat and S. Bhat, "Cellulose degrading enzymes and their potential industrial applications," Biotechnology Advances, vol. 15, no. 3-4, pp. 583-620, 1997.

[17] D. R. Kashyap, P. K. Vohra, S. Chopra, and R. Tewari, "Applications of pectinases in the commercial sector: a review," Bioresource Technology, vol. 77, no. 3, pp. 215-227, 2001.

[18] S. N. Gummadi and T. Panda, "Purification and biochemical properties of microbial pectinases-a review," Process Biochemistry, vol. 38, no. 7, pp. 987-996, 2003.

[19] D. Silva, K. Tokuioshi, E. da Silva Martins, R. da Silva, and E. Gomes, "Production of pectinase by solid-state fermentation with Penicillium viridicatum RFC3," Process Biochemistry, vol. 40, no. 8, pp. 2885-2889, 2005.

[20] P. E. Yuli, M. T. Suhartono, Y. Rukayadi, J. K. Hwang, and Y. R. Pyun, "Characteristics of thermostable chitinase enzymes from the indonesian Bacillus sp.13.26," Enzyme and Microbial Technology, vol. 35, no. 2-3, pp. 147-153, 2004.

[21] R. A. Lindberg, W. G. Rhodes, L. D. Eirich, and H. Drucker, "Extracellular acid proteases from Neurospora crassa," Journal of Bacteriology, vol. 150, no. 3, pp. 1103-1108, 1982.

[22] M. B. Rao, A. M. Tanksale, M. S. Ghatge, and V. V. Deshpande, "Molecular and biotechnological aspects of microbial proteases," Microbiology and Molecular Biology Reviews, vol. 62, no. 3, pp. 597-635, 1998.

[23] W. D. Glanzman, "Intentionally mummified remains of the pre-Islamic period in South Arabia," Canadian Association for Physical Anthropology Newsletter, no. 1, pp. 2-7, 2005.

[24] NEWSBRIEFS, "Mummified bodies found in North Yemen," Archaeology, vol. 37, p. 83, 1984.

[25] Y. M. Abdullah, Papers in History and Archaeology of Yemen, 1986, (Arabic).

[26] R. Boano, E. Fulcheri, R. Grilletto, E. Leospo, and E. Rabino Massa, "Histological analysis and staining techniques modified and verified on ancient mummified tissues to study microorganism infestations," Bollettino Della Societa Italiana di Biologia Sperimentale, vol. 75, no. 7-8, pp. 39-45, 1999.

[27] K. B. Raper and D. J. Fennell, The Genus Aspergillus, Williams and Wilkins, Baltimore, Md, USA, 1965.

[28] M. B. Ellis, Dematiacious Hypomycetes, Commonwealth Mycological Institute, Kew, UK, 1971.

[29] H. Barnett and B. Hunter, Illustrated Genera of Imperfect Fungi, The American Phytopathological Society, APS, St. Paul, Minn, USA, 4th edition, 1999.

[30] R. M. Teather and P. J. Wood, "Use of Congo red-polysaccharide interactions in enumeration and characterization of cellulolytic bacteria from the bovine rumen," Applied and Environmental Microbiology, vol. 43, no. 4, pp. 777-780, 1982.

[31] L. Hankin, M. Zucker, and D. C. Sands, "Improved solid medium for the detection and enumeration of pectolytic bacteria," Applied Microbiology, vol. 22, no. 2, pp. 205-209, 1971. 
[32] S. C. Hsu and J. L. Lockwood, "Powdered chitin agar as a selective medium for enumeration of actinomycetes in water and soil," American Society for Microbiology, vol. 29, no. 3, pp. 422426, 1975.

[33] R. R. Paterson and P. D. Bridge, Biochemical Techniques for Filamentous Fungi, International Mycological Institute, CAB International, Surrey, UK, 1994.

[34] S. B. Oyeleke, E. C. Egwim, and S. H. Auta, "Screening of Aspergillus flavus and Aspergillus fumigatus strains for extracellular protease enzyme production," Journal of Microbiology and Antimicrobials, vol. 2, no. 7, pp. 83-87, 2010.

[35] M. Ghraib, K. A. Youssef, and M. M. Nour EL-Deen, "Biodegradation of some cellulose wastes," Faculty of Education, Ain Shams University, vol. 16, pp. 87-105, 1992.

[36] H. O. Eggins and G. J. Pugh, "Isolation of cellulose-decomposing fungi from the soil," Nature, vol. 193, no. 4810, pp. 9495, 1962.

[37] O. A. G. Ali, "Formation of protease by Aspergillus fumigatus and Pencillium sp," King Saud University-Science, vol. 4, no. 2, pp. 127-136, 1992.

[38] G. L. Miller, "Use of dinitrosalicylic acid reagent for determination of reducing sugar," Analytical Chemistry, vol. 31, no. 3, pp. 426-428, 1959.

[39] P. Bernfeld, "Enzymes of starch degradation and synthesis," Advances in Enzymology and Related Subjects of Biochemistry, vol. 12, pp. 379-428, 1951.

[40] R. T. Sherwood, "Pectin lyase and polygalacturonase production by Rhizoctonia solani and other fungi," Phytopathology Journal, vol. 56, pp. 279-286, 1966.

[41] Z. I. Kertesz, The Pectic Substances, Interscience, New York, NY, USA, 1951.

[42] P. O. Olutiola and O. A. Akintund, "Pectin lyase and methylesterase production by Penicillium citrinum," Transactions of the British Mycological Society, vol. 72, pp. 49-55, 1979.

[43] J. Monreal and E. Reese, "The chitinase of Serratia marcescens," Canadian Journal of Microbiology, vol. 15, no. 7, pp. 689-696, 1969.

[44] O. Folin and V. Ciocalteu, "On tyrosine and tryptophane determinations in proteins," The Journal of Biological Chemistry, vol. 73, no. 2, pp. 627-650, 1927.

[45] O. Lowry, N. J. Rosebrouph, A. L. Farr, and R. J. Randall, "Protein measurement with the Folin phenol reagent," The Journal of Biological Chemistry, vol. 193, no. 1, pp. 265-275, 1951.

[46] F. Rojo-Pérez, Riesgos Ocupacionales por Manejo de Restos Momificados. Tesis de Licenciatura en Antropología Física, Escuela Nacional del Antropología e Historia, UNAM, Mexico City, Mexico, 1998.

[47] M. A. Shabbir, A. M. Khan, M. Khan, M. Iqbal, and F. Ahmad, "Fungal biodeterioration: a case study in the Zoological museum of the Punjab University," Journal of Animal and Plant Sciences, vol. 17, pp. 3-7, 2007.

[48] P. F. Hamlyn, Fungal Biotechnology, British Mycological Society, Newsletter, 1998.

[49] L. V. Ray, A. W. Pal, A. K. Ghosh, and P. C. Chattodyay, "Cellulase and $\beta$-glocosidase from Aspergillus niger and sacchrification of some cellulose wastes," Journal of Microbiology and Biotechnology, vol. 8, pp. 85-94, 1993.

[50] D. Silva, E. da Silva Martins, R. da Silva, and E. Gomes, "Pectinase production by Penicillium viridicatum RFC3 by solid state fermentation using agricultural wastes and agro-industrial by-products," Brazilian Journal of Microbiology, vol. 33, no. 4, pp. 318-324, 2002.
[51] E. S. Martins, D. Silva, R. Da Silva, and E. Gomes, "Solid state production of thermostable pectinases from thermophilic Thermoascus aurantiacus," Process Biochemistry, vol. 37, no. 9, pp. 949-954, 2002.

[52] S. R. Patil and A. Dayanand, "Optimization of process for the production of fungal pectinases from deseeded sunflower head in submerged and solid-state conditions," Bioresource Technology, vol. 97, no. 18, pp. 2340-2344, 2006.

[53] E. F. Sharaf, "A potent chitinolytic activity of Alternaria alternata isolated from Egyptian black sand," Polish Journal of Microbiology, vol. 54, no. 2, pp. 145-151, 2005.

[54] E. F. Sharaf, A. Q. El-Sarrany, and E. M. El-Deeb, "Biorecycling of shrimp shell by Trichoderma viride for production of antifungal chitinase," African Journal of Microbiology Research, vol. 6, no. 21, pp. 4538-4545, 2012.

[55] A. A. Mohammed and N. A. Hussein, "Proteolytic and lipolytic activity of fungi isolated from luncheon meat and poultry in Assiut city," Assiut Veterinary Medical Journal, vol. 50, no. 100, pp. 100-113, 2004. 

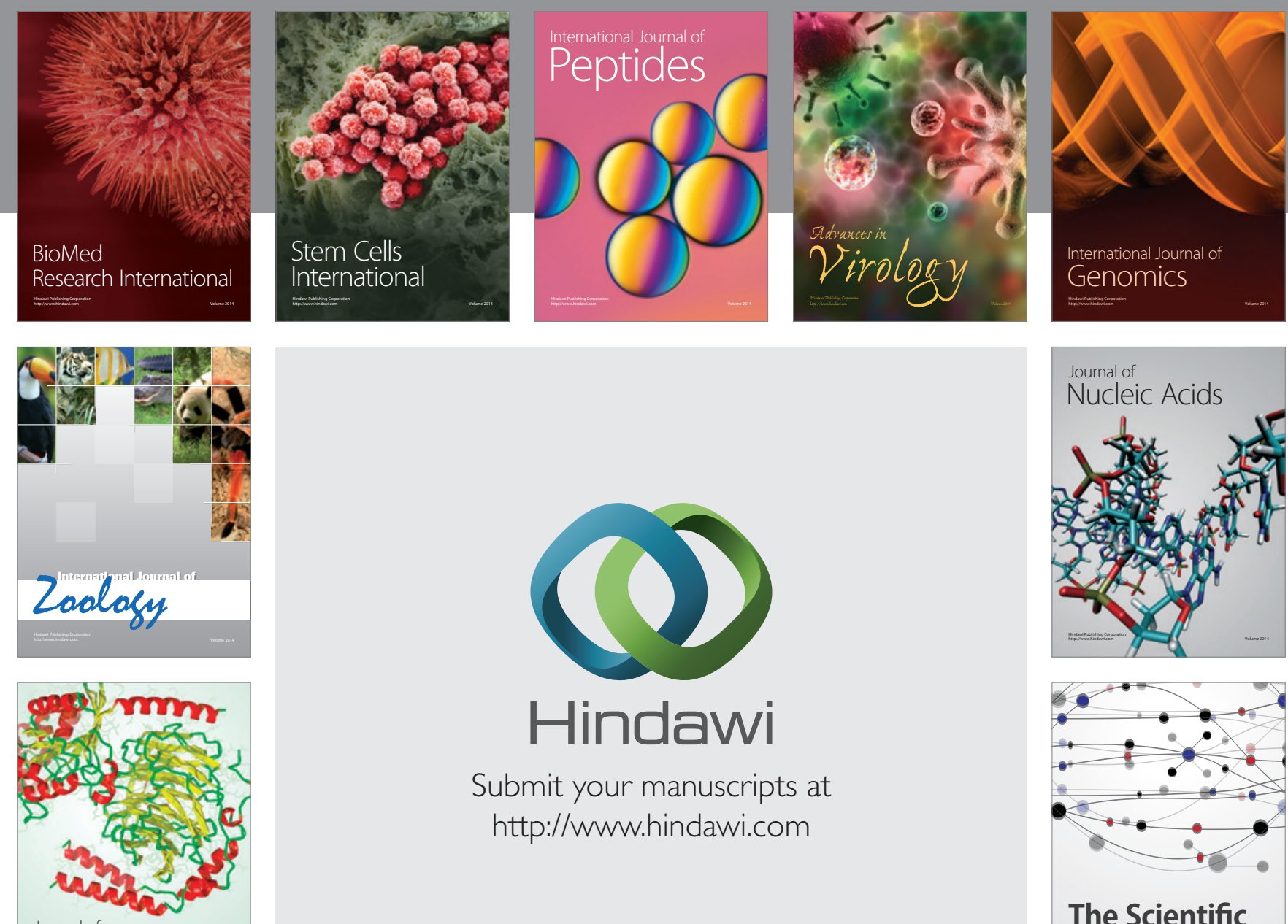

Submit your manuscripts at

http://www.hindawi.com

Journal of
Signal Transduction
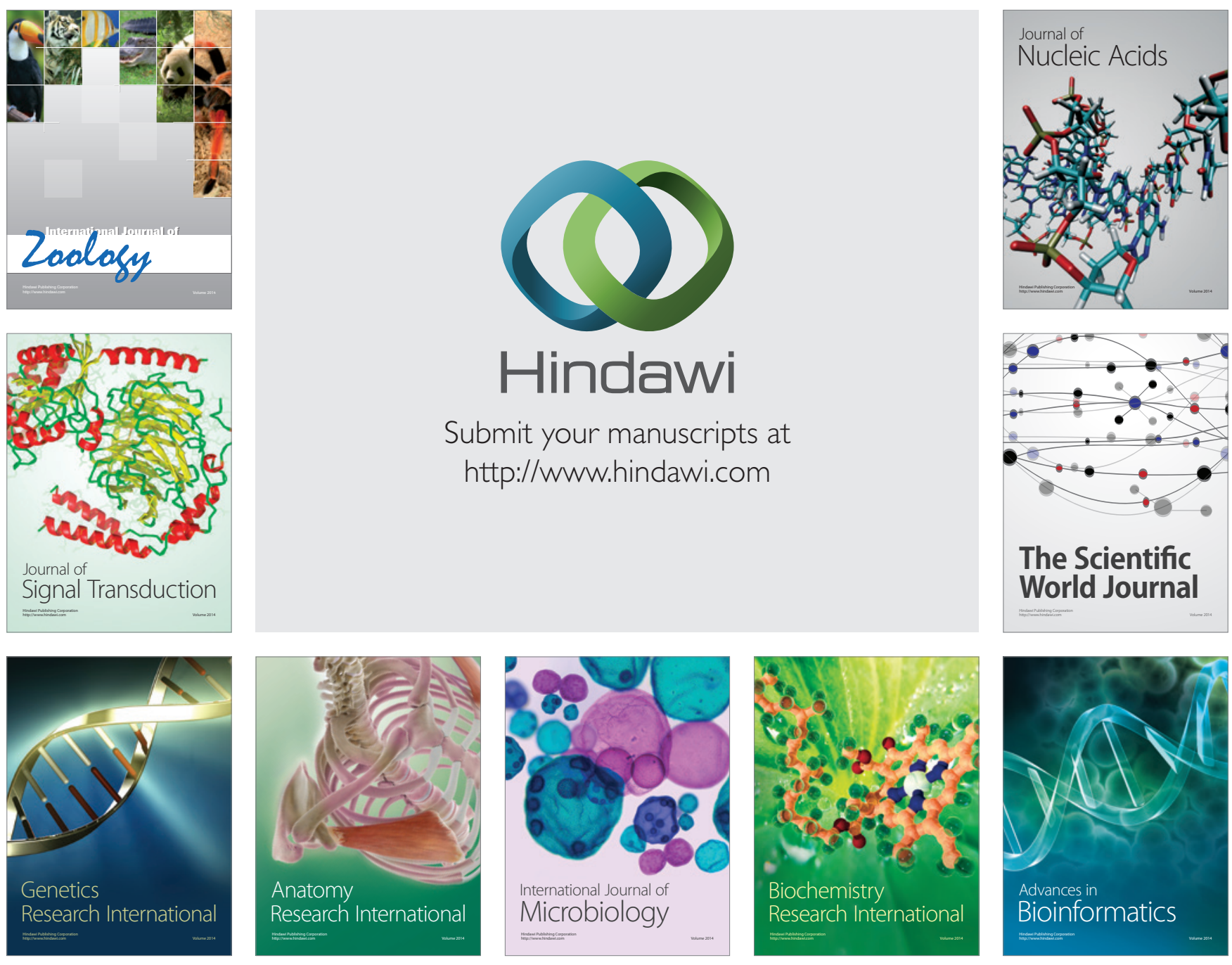

The Scientific World Journal
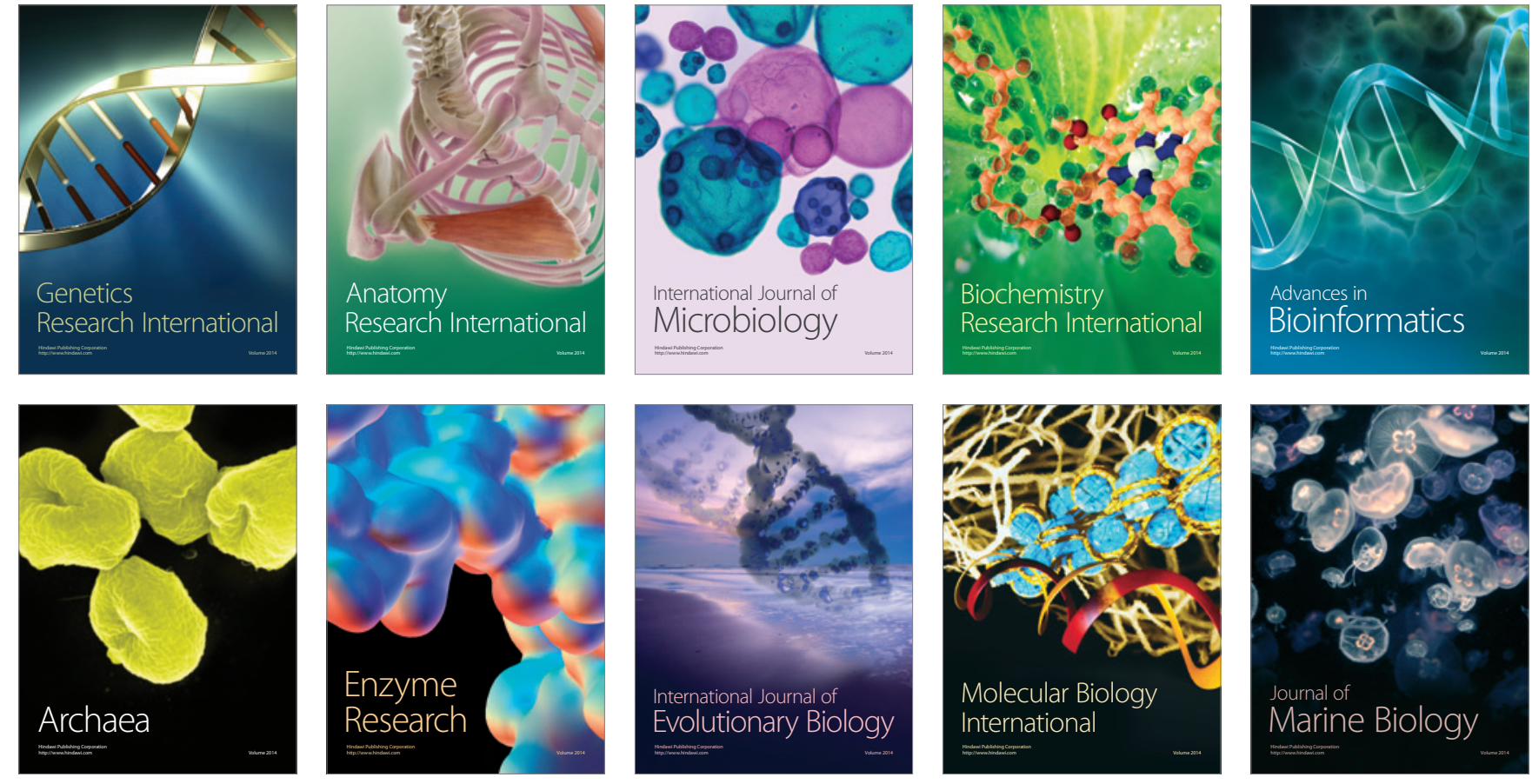